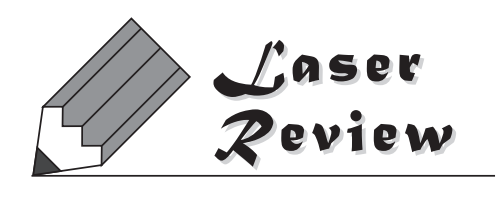

\title{
混合カオス信号の独立成分分析とカオス解析
}

\author{
梅野 健 \\ 独立行政法人 情報通信研究機構（
}

Independent Component Analysis of Chaotic Mixtures and Chaotic Analysis

\begin{abstract}
Ken UMENO
National Institute of Information and Communications Technology, 4-2-1 Nukui Kitamachi, Koganei, Tokyo 184-8795
\end{abstract}

(Received May 10, 2011)

\begin{abstract}
The key ingredient of signal analysis is to find a set of "natural basis functions" which are orthogonal to each other and which can be used as an orthogonal expansion basis. Our recent findings by simulations and experiments in a real physical environment that chaotic mixtures can blindly be separated into "natural chaotic sources" show that such chaotic sources can be used as orthogonal basis functions for spectrum analysis. Next, we show that such spectrum analysis based on the generalized Fourier expansion in terms of chaotic basis functions can be constructed by using Lebesgue spectrum analysis of ergodic theory. Furthermore, mixing property is proven by the existence of a complete orthonormal function of Lebesgue spectrum and finally a new orthogonal code based on the primitive root of a prime $\mathrm{p}$ called primitive root code is introduced for our chaotic spectrum analysis.
\end{abstract}

Key Words: Laser chaos, Independent component analysis, Mixing, Lebesgue spectrum, Fourier analysis

1. はじめに

未知の信号の特徵付けをする際, 所謂フーリエ解析の 様に, 常にサイン波の様な周期関数で展開するのが適切 かという問題は, 特に信号がカオスの場合, より顕著に 表れる，例えば，レーザーカオス信号がカオスであるの は, そのスペクトルが連続であるからという論法がある が, それはレーザーカオス信号が単純な周期関数の線形 和で書けないという意味でしかなく，連続なスペクトル を持つ信号がカオス信号だけでなく，例えば，観測され たカオス信号のパワースペクトルから，各スペクトルに 相当する信号にランダム位相を加えたランダム信号も全 く同じパワースペクトルを持つことから, 周波数スペク トルの連続性が, カオス性の証明にはならないという問 題がある.つまりサイン波の様な直交周期関数を基底と する解析方法では, レーザーカオスの様な信号が純粋に ランダムな信号か, 決定論的メカニズムを持つ確率的振 る舞いである決定論的カオスを示す“カオス性を有する か”の証明ができないのである。では, カオス信号の場 合, 周波数スペクトル解析に代わるカオス性を特徵付け る解析方法があるだろうか? その様な解析方法は, 当 然, 周波数スペクトルによる解析方法と異なり, カオス 性との関係が明確であり, カオス性がある場合はこの解 析方法により, カオス性が証明されなければいけない. 本稿では, この様な解析方法が, カオス信号を基準信号
とする通信システムを模索する中で得られ，カオス信号 を自然な基底とする信号分解が具体的な例で可能であ り，逆にフーリ工解析と同様に，一般の信号がカオス信 号の“自然な基底”として分解できることから，自然にカ オス解析可能な解析方法一カオス解析一が導出されるこ とを示す。

$$
\text { 信号 }=\text { カオス信号 }{ }_{1}+\text { カオス信号 }{ }_{2}+\cdots
$$

ここで言う“自然な基底”とは，レーザーカオス信号の様 なカオス信号がカオス性を保有したまま直交する直交信 号の集合を指す。同直交信号成分の存在そのものがカオ ス性の証明となるという意味において, カオス信号の解 析において“自然”な直交展開を与える直交信号であるこ とをいう。そこで，本解析の鍵となるのが，そもそも力 オス信号が“自然な基底”となり得るかであり，その検証 のため, 独立成分分析という信号分解する (原信号) 直交 成分が何かを知らなくても複数の信号を入力することに より直交成分に信号分離できるブラインド信号分離法を 用いることにより，復元した基底が，カオス性を有する “自然な直交基底”となるか否かを示すことである。最 近, ブラインド信号分離法の特徵から, 元のカオス信号 (=直交基底)が未知であっても, 混合カオス信号として 与える信号から, 基底となるカオス信号 $(=$ 自然な基底 $)$ を完全に分解できることが解ってきた ${ }^{3-7)}$. これらの研 究により, 一般の信号が, 直交するカオス信号の線形和 
として自然に表現できることがわかるので, 後は, 力学 系のエルゴード理論により，選択される“自然なカオス 基底”とは何かを決めるロジックが解ればよい，それが， エルゴード理論によりカオスカ学系と直交基底との関係 を明瞭に示すルベーグスペクトル分解理論であり，その ルベーグスペクトル分解の直交基底で展開できること が，カオス性と密接に関わっており，カ才ス性を意味す る混合性を厳密に証明する概念であることを示す。すな わち，ルベーグスペクトルに対応する直交基底で信号を 分解する時には, サイン波に基づくフーリエスペクトル 展開と異なり，その信号のカオス性を証明することがで きるのである，さらに，このスペクトルが直接カオス性 を定量的に評価するリアプノフ特性指数と密接に関係す ることから，信号のカオス性を証明するだけでなく，カ オス性を定量的に評価することもできるのである. 次章 からこの新しいカオス解析法の背景とカオス性との関連 を解説した後, 最後に, 本信号解析手法のレーザーカオ スの分野へのインパクトを概観する。

\section{2. 混合カオス信号の独立成分分析}

信号解析のエッセンスは, 信号の基本直交成分への分解

$$
\text { 信号 }=a_{1} \text { 基底 }{ }_{1}+a_{2} \text { 基底 }{ }_{2}+\ldots .
$$

にあるといっても過言ではない，ところが何が自然な基 底(基本直交成分)であるかは，一般には不明である。こ の様に，何が基本直交成分であるか不明な状況で，信号 分解用の基本直交成分を具体的に抽出できるのが，独立 成分分析である。ここでは，まず，ある程度理想的なカ オ人信号 (例：2次以上のチェビシェフ多項式から生成さ れる系列)の場合, 独立成分分析が㛜密に基本成分を抽 出できることを示し，実際の物理系により得られたより 自然なカオス信号の場合でも独立成分分析により分離で きることを示す，まず，カオスを生成することで有名な ロジスティック写像

$$
Y=4 X(1-X)
$$

が, $X=\sin ^{2}(\theta), Y=\sin ^{2}(2 \theta)$ と三角関数の 2 倍角の公式と して書けることに注意しょう。より一般の自然数 $m$ に対 して, $\cos (\theta)$ の $m$ 倍角の公式からなる関数 $T_{m}$ を

$$
\cos (m \theta)=T_{m}[\cos (\theta)]
$$

で定義しよう。この $T_{\mathrm{m}}(X)$ が直交多項式と知られるチエ ビシェフ多項式であり,

$$
T_{1}(X)=X, T_{2}(X)=2 X^{2}-1, T_{3}(X)=4 X^{3}-3 X, \cdots
$$

となり, $m$ が2以上の場合, チェビシェフ多項式 $T_{m}$ を写 像とする写像力学系の軌道は, カオス性を有することが 知られている. $m=2$ の場合, Fig. 1の様になり, 区間 $(-1,1)$ 上のカオス写像となっている.

一般に三角関数や楕円関数等の加法公式を有する周期

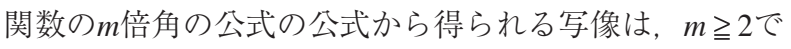

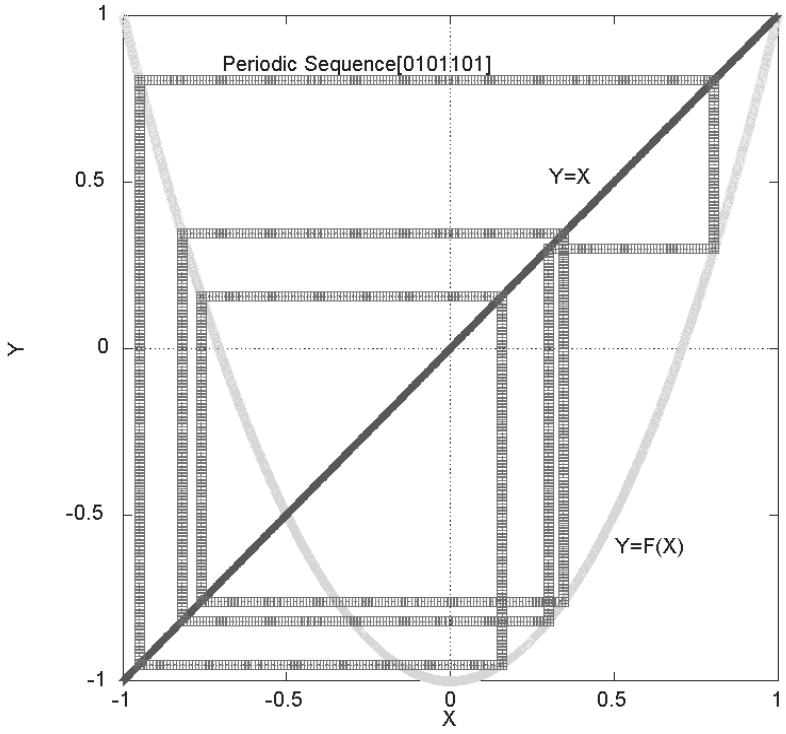

Fig. 1 2nd Chebyshev map and its trajectory.

カオス性を有し, さらに

リアプノフ特性指数 $=\mathrm{KS}$ エントロピー $=\log (m)$

となっていることが解る ${ }^{11}$. 即ち, これらのカオス系列 は，性質がよく解っているカオス信号と考えてよい. 今, ランダム行列で与えられる $2 \times 2$ の行列で, 2 次の チェビシェフカオス信号Xと3次のチェビシェフカオス 信号 $Y$ を次式の様に線形混合し，2本の混合信号 $Z_{1}, Z_{2}$ を 得るとする。

$$
Z_{1}=a_{1} X+a_{2} Y, \quad Z_{2}=a_{3} X+a_{4} Y
$$

独立成分分析とは，この混合された信号 $Z_{1}, Z_{2}$ のみで, どの様に混合されたか，オリジナル信号 $X, Y$ オ゙どの様 な信号かの情報は全く無しの未知の状態で，オリジナル 信号 $X$ と $Y$ を推定する信号処理方法である9，正確には， 原信号の確率分布関数がガウス分布でないという仮定が いるが，一般のカオス信号はガウス分布を持たない，つ まり非正規性を持つので, この非ガウス性 = 非正規性 の仮定は成立すると考えられる.中心極限定理による と，非正規性を持つ信号を多く線形混合すればするほ ど，混合された信号の確率分布関数はガウス分布に近付 くので，逆にこの独立成分分析法のプロセスとは，中心

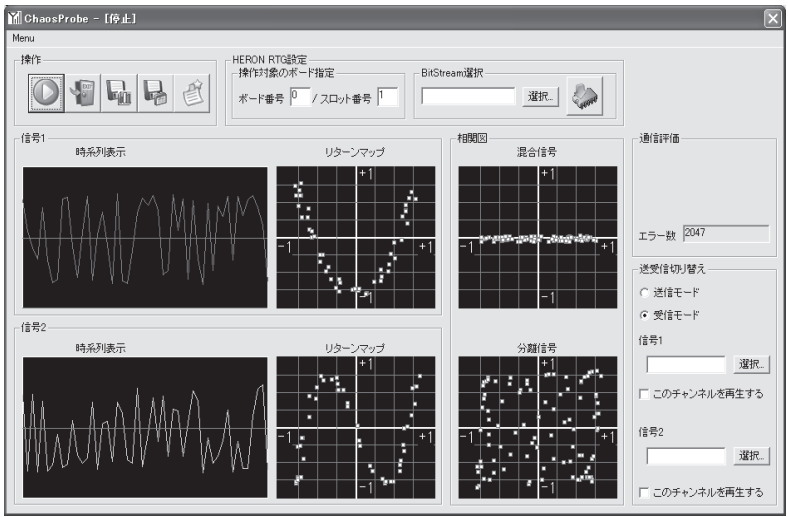

Fig. 2 Blind signal separation of chaotic mixtures. 
極限定理の極限操作と逆のプロセスと考えることができる

さて，このチェビシェフカオス信号の混合信号は， Fig. 2の様に著者のグループが構築した信号分離ソフト ウェアにより，分離された後のリターンプロットを見る と，きれいに2次のチェビシェフ系列(上部中央の図) と3 次のチェビシェフ系列(下部中央の図)に分離できること がわかる。

独立成分分析をする際は，2次のチェビシェフ写像を 使ったカオス系列を使うとか，3次のチェビシェフ写像 を使ったカオス系列を原信号として混ぜ合わせた信号を 使うといった情報を一切用いずに，混合信号のデータの みの処理でオリジナルカオス信号が復元できたことに注 意しよう。つまり, 復元するカオス信号に情報が埋め込 まれているならば, 独立成分分析法 (ICA = Independent Component Analysis)によってダイレクトに情報復元する 新しい通信方法 ${ }^{3,4,7)}$ が可能となる。2次のチェビシェフ系 列の場合，Fig. 1の通りxが正の場合を“1”，負の場合を “0”とすると，カオス系列と 2 值符号列を 1 対 1 に対応付け させることができる。これは力学系理論のシンボリック ダイナミクスの考えで2次のチェビシェフ写像がKSエン トロピーが $\log 2$ (1回の繰り返しにより平均1ビットの情 報を生成)を持つことの構成的な証明となっている，情 報をカオス系列で送れば, 受信側で, 復号用符号 (スペ クトル拡散通信の場合は, 逆拡散用拡散符号) 無しで, 復号できることとなる。著者はこういったチェビシェフ カオス系列の様な理想的なカオス信号を信号源とする夕゙ イレクトな復号を可能とする通信システムを従来のスペ クトル拡散や他のカオス通信と区別するためICA通信と 呼び，その基本的な性質を評価した。まず，基本信号源 が2つの場合だけでなく，より多数の場合も同様に信号 分離が可能であることを示した。

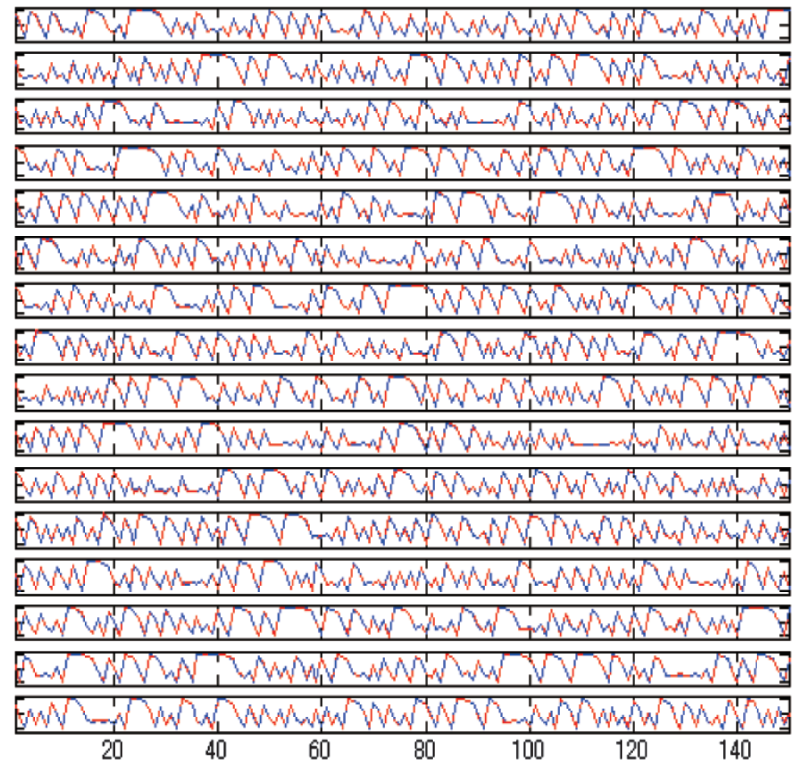

Fig. 3 Independent component analysis of 16 different mixtures of 16 Chebyshev chaotic sequence: Original source signals (blue) and recovered signals by ICA (red).
Fig. 3は16種類のチェビシェフカオス系列の混合信号 の分離結果である。信号源(オリジナルチェビシェフカ オス系列)を青とし，赤が，独立成分分析による分離後 の信号である。比較すると見事に一致していることがわ かる4).

当然, 混合する信号源の数を増加していけば，分離さ れた信号と信号源との誤差も増加する。ただ，現在 3Gとして標準化されているマルチユーザアクセス通信 のCDMA (符号分割多元接続) 通信と同様に，混合信号数 の増加に対して，信号分離性能の劣化は緩やかである $(\text { Graceful Degradation })^{7)}$. つまりユーザ数やデー夕量の 増加に対して必要なコスト増が緩やかなスケーラブル な通信システムを構築できる。よってこのカオスとブラ インド信号処理による通信システムは，従来の復号化法 を用いる通信方法と異なり ICA通信という新しい通信シ ステムというパラダイム構築としてその応用・展開が期 待ができる ${ }^{3,4)}$. 無論, 従来のスペクトル拡散通信の受 信側の逆拡散プロセスの前処理一例えばMIMO (Multiple-Inputs -Multiple Outputs) 型アーキテクチャの場 合一このICA処理を復号化ベースバンド処理の前処理と して併用することもでき，その場合は，ICA処理無しの 場合の従来法と比較して, 更に, 通信品質の向上が見达 まれる。

さて，ここまでの説明で，ある意味理想的なカオス信 号の混合信号とは，独立成分分析可能で，自然な直交基 底であるカオス信号を信号源としてブラインド信号分離
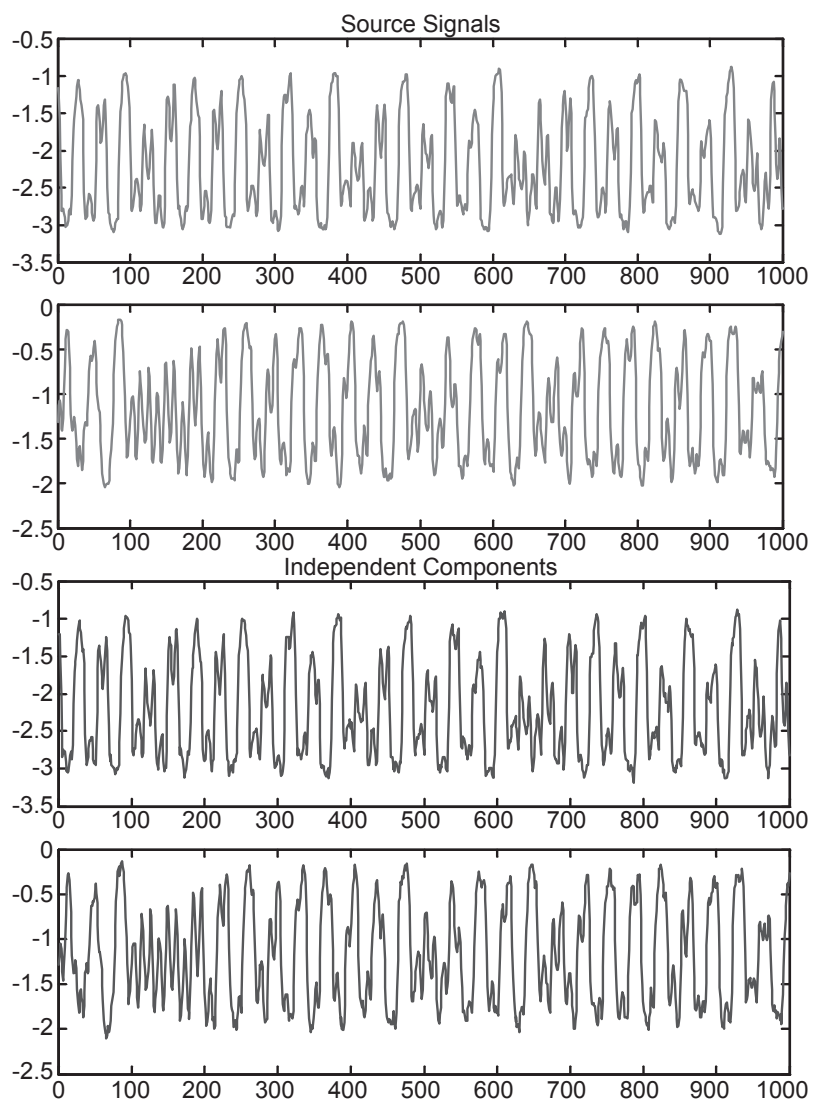

Fig. 4 Original chaotic sources (upper) generated by electronic circuits and recovered signals by ICA (lower). 
法で取得できることが解った

では, 原信号としてのカオス信号は, 数学的に簡単に 得られる理想的なカオス信号のみであろうか?

この問いに答えるために，我々は，Mackay-Glass方程 式という遅延のあるフェードバックによる生成する電子 回路上のカオス信号を2種類生成し，電子回路で混合し た結果を実験データとして独立成分分析した ${ }^{6)}$ 。その結 果は, Fig. 4にある様に，オリジナルカオス信号(上部) とICAによって分離した信号(下部)がよく一致している ことが解り，ICAによって“自然な直交基底”として抽出 されるカオス信号は, 数学的な理想的な信号だけでな く, “物理的なカオス信号” 自身も, “数学的に自然な直 交基底”としての役割を果たすことを示すものである.

では，レーザーカオスの場合はどうであろうか?

我々は，2種類の遅延フィードバックによる生成され るレーザーカオス信号を混合する場合も, ランダムな比 率のビームスピリッターで分波し合波することにより， レーザーカオス信号の混合信号を構成できることを示し た ${ }^{5)}$ ，その混合 (=合波された)レーザー信号を入力デー タとして独立成分分析を施すと，復元した信号は，電子 回路のカオスの場合と同じく，入力で用いたレーザーカ オスのオリジナル信号と比較してほとんど誤差なく再現 することが解った ${ }^{5)}$.つまり, 電子回路によるカオスで もレーザーカオスでも, 物理的に生成されたカオス信号 がチェビシェフ多項式による理想的なチェビシェフカオ ス系列と同様に，“自然な直交基底”としての役割を果た すことが解ったのである。この様に一般のカオス信号を カオス信号の直交基底で展開することは, 決して人工的 な産物でなく，このICAによる混合カオス信号のブライ ンド信号分離研究により, カオス信号を周期関数で周波 数スペクトルで展開するのではなく，カオス系列自身を 直交基底としてスペクトル分解するのが自然であること が解ったのである。

\section{3. ルベーグスペクトル解析}

2章の結果を更に抽象化し, 領域 $\Omega$ 上の力学系

$$
X_{n+1}=F\left(X_{n}\right)
$$

で生成される不変確率測度 $\rho(x) d x$ を有するカオス系列生 成写像 $F$ と, 下記の関数関係を有する正規直交関数系 $\left\{\phi_{\mathrm{k}, \mathrm{j}}\right\}$

$$
\phi_{\mathrm{k}, \mathrm{j}+1}(x)=\phi_{\mathrm{k}, \mathrm{j}} \circ F(x)
$$

を考える。ここで， $k$ は， $\Lambda$ という可算無限個の元から なる集合の一要素(スペクトル)であり，jは，0からめま での可算無限の整数とする。ささて, ここで, 一般性を失

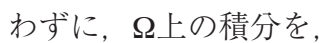

$$
<A>=\int_{\Omega} A(x) \rho(x) d x
$$

で定義し，内積 $<A, B>$ を

$$
<A, B>=\int_{\Omega} A(x) B(x) \rho(x) d x
$$

で定義すると，内積空間 $(\Omega,<\cdot, \cdot>)$ においてノルム\|A\|が 次式

$$
\|A\|^{2}=\left\langle A, A>=\int_{\Omega} A(x)^{2} \rho(x) d x \geqq 0\right.
$$

で与えられるノルム空間となり，更に同内積空間が，次 式で与えられる距離

$$
d(x, y)=\|x-y\|, \quad x, y \in \Omega
$$

が完備なら，同内積空間がヒルベルト空間 $H(\Omega, \rho)$ とな る. そして関数等式 (9) を満足する直交基底 $\left\{\phi_{\mathrm{k}, \mathrm{j}}\right\}$ が, こ のヒルベルト空間 $H$ 上の完全正規直交基底CONS (Complete Orthonormal System) である場合, 任意の $f \in H$ に対して,

$$
f(x)=a_{0}+\sum_{\mathrm{k} \in \Lambda} \sum_{\mathrm{j}=0, \ldots, \infty} a_{\mathrm{k}, \mathrm{j}} \phi_{\mathrm{k}, \mathrm{j}}(x)
$$

と一般化フーリエ展開できる。 このCONS $\left\{\phi_{\mathrm{k}, \mathrm{j}}\right\}$ による展 開を，(9)式を満足する直交基底 $\left\{\phi_{\mathrm{k}, \mathrm{j}}\right\}$ のスペクトル $k \in \Lambda$ は，ルベーグ測度という確率測度の分解を与えるルベー グスペクトル に に他ならないので，式(14)による一般 フーリエ展開を, 力学系 $F$ に由来する直交基底 $\left\{\phi_{\mathrm{k} . \mathrm{j}}\right\}$ によ る展開をルベーグスペクトル展開と考えることができ る。つまり，式(14)は，ヒルベルト空間 $H$ 上の任意の関 数 $f$ のオス写像 $F$ に由来するCONS $\left\{\phi_{\mathrm{k}, \mathrm{j}}\right\}$ 関数によるスペ クトル展開を与える式となっている。 その様なルベーグ スペクトルを持つCONS $\left\{\phi_{\mathrm{k}, \mathrm{j}}\right\}$ 関数の具体例として, カオ ス写像であるチェビシェフ多項式 $T_{\mathrm{q}}$ にる構成：

$$
\phi_{\mathrm{k}, \mathrm{j}}(x)=\sqrt{2} T_{\mathrm{kq}}{ }^{\mathrm{j}}(x)
$$

が知られている ${ }^{2)}$ 。ここで， $k$ は，ある適当な 2 以上の自 然数 $q$ で割り切れない自然数の集合 $\Lambda=\{k \geqq 11 k \bmod q \neq 0\}$ を示し，ルベーグスペクトルの関係式 (9)は,

$$
\phi_{\mathrm{k}, \mathrm{j}} \circ T_{\mathrm{q}}(x)=\sqrt{2} T_{\mathrm{kq}} \mathrm{j}+1(x)=\phi_{\mathrm{k}, \mathrm{j}+1}(x)
$$

を満足する ${ }^{2)}$. チェビシェフ多項式はヒルベルト空間 $H$ 上の完全な直交関数系を成すことが知られているので, チェビシェフカオス関数自身が, CONS，つまり任意の 関数をチェビシェフ多項式(15)を利用するルベーグスペ クトル展開(式(14))は，チェビシェフカオス関数自身を 直交基底とする信号の展開を与えていることになる。た だし， $\left\{k q^{j} \mid k \bmod q \neq 0, j \geqq 0\right\}$ とした時に，全ての自然数 を $(k, j)$ と1対1で表現できることに注意する。ここに， 第2章でICAにより発見法的に示唆されたカオス信号を 基底とする信号展開方法が，このルベーグスペクトル解 析によって明確な基礎が与えられる。また，このルベー グスペクトルCONSはユニークである必要はなく，例えば,

$$
U_{m}(\cos \theta)=\sin m \theta
$$

なる第2種チェビシェフ関数 $U_{\mathrm{m}}$ により，(18)式 


$$
\psi_{\mathrm{k}, \mathrm{j}}(x)=\sqrt{2} U_{\mathrm{kq}} \mathrm{j}(x)
$$

で与えられるCONSは，q次のチェビシェフカオス写像 $F=T_{\mathrm{q}}$ と, ルベーグスペクトル条件(9) 式に相当する (19) 式

$$
\psi_{\mathrm{k}, \mathrm{j}} \circ T_{\mathrm{q}}(x)=\sqrt{2} U_{\mathrm{kg} \mathrm{j}^{\mathrm{j}}}(x)=\psi_{\mathrm{k}, \mathrm{j}+1}(x)
$$

を満足することがわかる。この第2種チェビシェフ関数 もヒルベルト空間 $H$ 上のCONSを構成することが知られ ており，カオス信号展開を与えるルベーグスペクトル基 底CONSは，ユニークに定まるのではなく，一般に複数 個あることが解る。

\section{4. 混合性の証明}

ここでは, ルベーグスペクトルCONSを持つ力学系 （8）は，カオス性の基本的な特徵である混合性を持つこ とを証明する。つまり，このルベーグスペクトルCONS $\left\{\phi_{\mathrm{k}, \mathrm{j}}\right\}$ を基底とするカオス信号展開は, カオスカ学系の 根本的な性質である混合性を基礎付けるものとなる。

さて, 混合性は, ヒルベルト空間 $H$ 上の任意の関数 $u(x), v(x)$ により，時間相関が， $n \rightarrow \infty て ゙$,

$$
<u, L^{\mathrm{n}} v>=\int_{\Omega} u(x) L^{\mathrm{n}} v(x) \rho(x) d x \rightarrow<u><v>
$$

と無相関となることである，但し，Lは，写像Fによって 誘導された時間発展演算子とし，任意の $\phi(x) \in H$ に対し，

$$
L \phi=\phi \circ F
$$

が成立する.ここで, $u(x), v(x)$ のルベーグスペクトル CONSの展開(フーリエ展開)を,

$$
\begin{aligned}
& u(x)=a_{0}+\sum_{\mathrm{k} \in \Lambda} \sum_{\mathrm{j}=0, \ldots \infty \infty} a_{\mathrm{k}, \mathrm{j}} \phi_{\mathrm{k}, \mathrm{j}}(x) \\
& v(x)=b_{0}+\sum_{\mathrm{k} \in \Lambda} \sum_{\mathrm{j}=0, \ldots, \infty} b_{\mathrm{k}, \mathrm{j}} \phi_{\mathrm{k}, \mathrm{j}}(x)
\end{aligned}
$$

とするとその展開は一意に決まる。ここで,

$$
a_{0}=<u(x)>, b_{0}=\langle b(x)>,
$$

が成立し，ルベーグスペクトルCONS $\left\{\phi_{\mathrm{k}, \mathrm{j}}\right\}$ の完全性の仮 定より,

$$
a_{\mathrm{k}, \mathrm{j}}, b_{\mathrm{k}, \mathrm{j}} \rightarrow 0 \text { for } j \rightarrow \infty
$$

が成り立つ. 又, ルベーグスペクトルCONS $\left\{\phi_{\mathrm{k}, \mathrm{j}}\right\}$ の完全 性よりパーセバルの等式

$$
\begin{gathered}
\|u\|^{2}=\left\langle u, u>=a_{0}{ }^{2}+\sum_{\mathrm{k} \in \Lambda} \sum_{\mathrm{j}=0, \ldots, \infty} a_{\mathrm{k}, \mathrm{j}}{ }^{2}\right. \\
\|v\|^{2}=\langle v, v\rangle=b_{0}{ }^{2}+\sum_{\mathrm{k} \in \Lambda} \sum_{\mathrm{j}=0, \ldots, \infty} b_{\mathrm{k}, \mathrm{j}}{ }^{2}
\end{gathered}
$$

が成立する。 今, $M$ を $\|v\|^{2}=M<\infty な る$ 正の定数とする と，任意のEに対して，ルベーグスペクトルCONS $\left\{\phi_{\mathrm{k}, \mathrm{j}}\right\}$ の完全性により, 下記の不等式

$$
\sum_{\mathrm{k} \in \Lambda} \sum_{\mathrm{j}=\mathrm{N}(\varepsilon)+1, \ldots, \infty} a_{\mathrm{k}, \mathrm{j}}{ }^{2} \leqq \varepsilon^{2} / M
$$

が成立する様な, 自然数 $N(\varepsilon)$ が常に存在する. この時,

$$
\begin{array}{r}
u_{0}(x)=a_{0}+\sum_{\mathrm{k} \in \Lambda} \sum_{\mathrm{j}=0, \ldots, \mathrm{N}(\varepsilon)} a_{\mathrm{k}, \mathrm{j}} \phi_{\mathrm{k}, \mathrm{j}}(x) \\
\delta u(x)=\sum_{\mathrm{k} \in \Lambda} \sum_{\mathrm{j}=\mathrm{N}(\varepsilon)+1, \ldots, \infty} a_{\mathrm{k}, \mathrm{j}} \phi_{\mathrm{k}, \mathrm{j}}(x)
\end{array}
$$

と定義すると, $u(x)=u_{0}(x)+\delta u(x)$ となり, 一方, $v$ に 関して次式

$$
L^{\mathrm{n}} v=b_{0}+\sum_{\mathrm{k} \in \Lambda} \sum_{\mathrm{j}=0, . ., \infty} b_{\mathrm{k}, \mathrm{j}} \phi_{\mathrm{k}, \mathrm{j}+\mathrm{n}}(x)
$$

が成立するので，ルベーグスペクトルCONSの直交性に より，任意の $n>N(\varepsilon)$ なる $n$ に対して, 時間相関が,

$$
<u, L^{\mathrm{n}} v>=\left\langle u_{0}, L^{\mathrm{n}} v>+<\delta u, L^{\mathrm{n}} v>=\left\langle u>\left\langle v>+<\delta \mathrm{u}, L^{\mathrm{n}} v\right\rangle\right.\right.
$$

が成立する，この時，コーシー＝シュワルツの不等式より，

$$
\begin{array}{r}
\left|<u, L^{\mathrm{n}} v>-<u><v>\right|=\left|<\delta u, L^{\mathrm{n}} v>\right| \leqq\|\delta u\|\left\|L^{\mathrm{n}} v\right\| \leqq \\
\varepsilon / \sqrt{M} \times \sqrt{M}=\varepsilon
\end{array}
$$

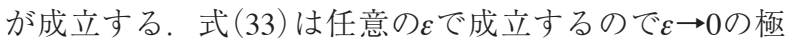
限をとることにより，混合性(20)が証明できた。混合性 はエルゴード性よりも強い条件で，カオスの最も基本的 な特徴である。つまり，その混合性とルベーグスペクト ルCONS (完全直交基底)による信号展開可能性と密接な 関係があることが解る。

\section{5. カオス解析用符号一原始根符号}

次にフーリエ解析を計算する時に，実際には離散フー リエ変換により計算する様に，このルベーグスペクトル によるカオス解析には，離散版のルベーグスペクトル展 開の直交基底が必要であることから，それを求めてみ る。今，2次元力学系を考える。

$$
\begin{gathered}
x^{\prime}=2 x^{2}-1 \\
y^{\prime}=2 x y
\end{gathered}
$$

ここで, $x=\cos (a), y=\sin (a)$ とおくと式(34) と (35) は, コサイン関数とサイン関数の 2 倍角の公式に他なら ず，複素平面を $z=x+i y$ と考えると，式(34)と (35) は, 複素平面上の単位円上の写像で, 位相 $a$ を倍する写像に 相当する。実数軸へ射影すると，コサイン関数の2倍角 写像となり，それは，ルベーグスペクトルCONSを構成 したチェビシェフカオス写像の2次多項式 $T_{2}$ に他ならな い.よってこの写像は, カオスの軌道不安定性を示すリ アプノフ特性指数が $\log 2$ となることがわかる。同様に 複素平面上の原点を中心とする単位円上の点に対して $\exp (i \theta) \rightarrow \exp (q i \theta)$ となる，位相が $q$ 倍角にマップされる 写像 $F_{q}$ を構成することができる。 2008年に発見されたこ の $q$ 倍角写像に由来する原始根符号 ${ }^{8)}$ は, 任意の素数 $p$ に 対して，その原始根 $q$ を考えることにより，峳密に直交 する複素平面上の単位円上の $p$ 乗根を要素とする複素力 オス周期軌道を構成する。， 今，素数 $p$ の原始根を $q$ とする 
と, その $p-1$ 個の $q$ の゙き乗集合はそれぞれ $p$ に関する合 同をとることにより， $\{1,2, \ldots, p-1\}$ と等しいことが解る.

$$
\left\{1, q, q^{2}, \cdots, q^{\mathrm{p}-2}\right\}(\bmod p)=\{1,2, \ldots, p-1\}
$$

さらに, これらの $q^{\mathrm{j}}(\bmod p)$ を, 複素数 $\exp \left(-i 2 \pi q^{\mathrm{j}} / p\right)$ に 変換すると, フェルマーの小定理 $q^{\mathrm{p}-1} \bmod p=1$ から, 複 素平面上の単位円上の $q$ 倍角カオス写像の厳密な $p$-1周期 点となる。 もし，ここで

$$
\phi_{\mathrm{k}, \mathrm{j}}=\exp \left(-i 2 \pi k q^{\mathrm{j}} / p\right) \text { for } k=0,1, \cdots, p-1
$$

と定義すると，それは，離散フーリエ変換を与えるユニ タリー行列の要素となることに着目し, $p-1$ 本の複素べ クトル

$$
v[k]=\left[1, \phi_{\mathrm{k}, 0}, \phi_{\mathrm{k}, 1}, \cdots \ldots, \phi_{\mathrm{k}, \mathrm{p}-2}\right] \text { for } k=1, . ., p-1
$$

と一本の複素ベクトル

$$
v[0]=[1,1,1, \cdots \ldots, 1]
$$

を考える時，このp本のベクトルは互いに直交し， $p \times p$ のユニタリー行列を与えることになる ${ }^{8)}$. 当然, ユニタ リー行列は複素直交行列で, このユニタリー行列の直交 性から, 既存の離散フーリ工変換とは異なる, 再び離散 直交力オス信号 (37) - (38)による信号展開を与え, 通常 の離散フーリエ変換を送信側受信側の変調方式とする OFDM (Orthogonal Frequency Division Multiplexing) 通信と は異なる, カオスベースの新しいOFDM(ここではカオ スOFDMとする)が構成される。 これも離散值版のカオ 又解析と考えることができる，更に，任意の素数 $p$ 対 して, 原始根の数は, オイラー関数 $\phi(x) に よ り, \phi$ $(p-1)$ 個の原始根を持ち, 原始根 $q$ を変えることにより, 写像が変わり, 一般にq倍角写像はリアプノフ指数 $\log$ $(q)$ を持つことから, 原始根とカオス性は密接に関連性 を持つことがわかり，原始根に応じて質的に異なる軌道 （原始根符号 $\rightarrow$ ユニタリー行列 $(q)$ )を与えることにな

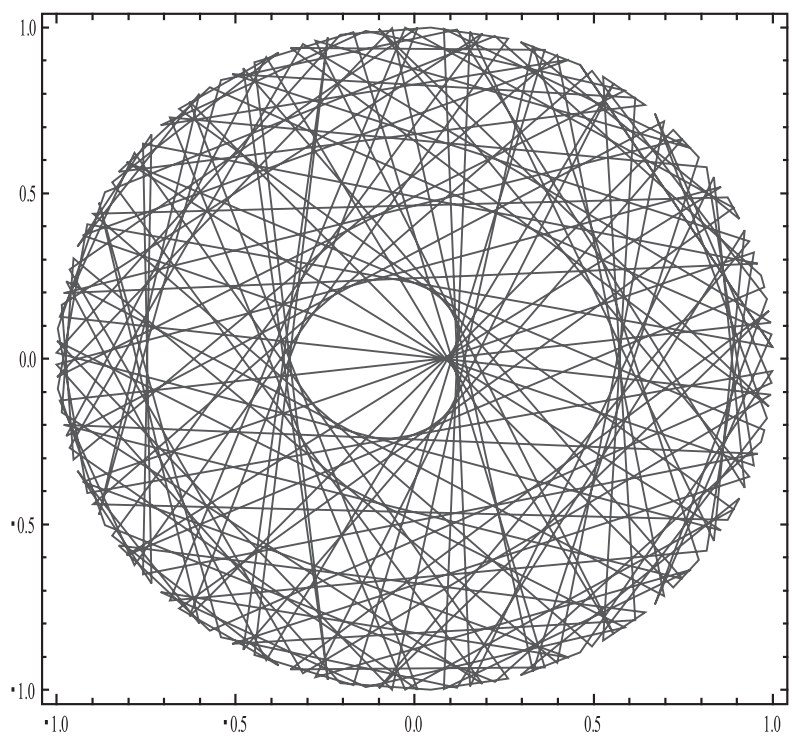

Fig. 5 IQ Orbit of Primitive Root Code. $(p=173, q=66)$

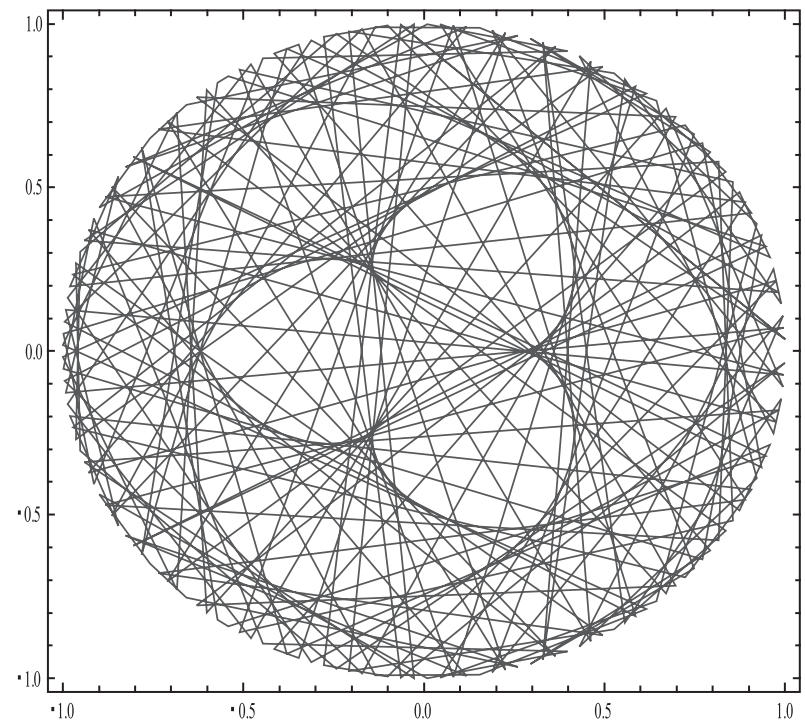

Fig. 6 IQ Orbit of Primitive Root Code. $(p=173, q=46)$

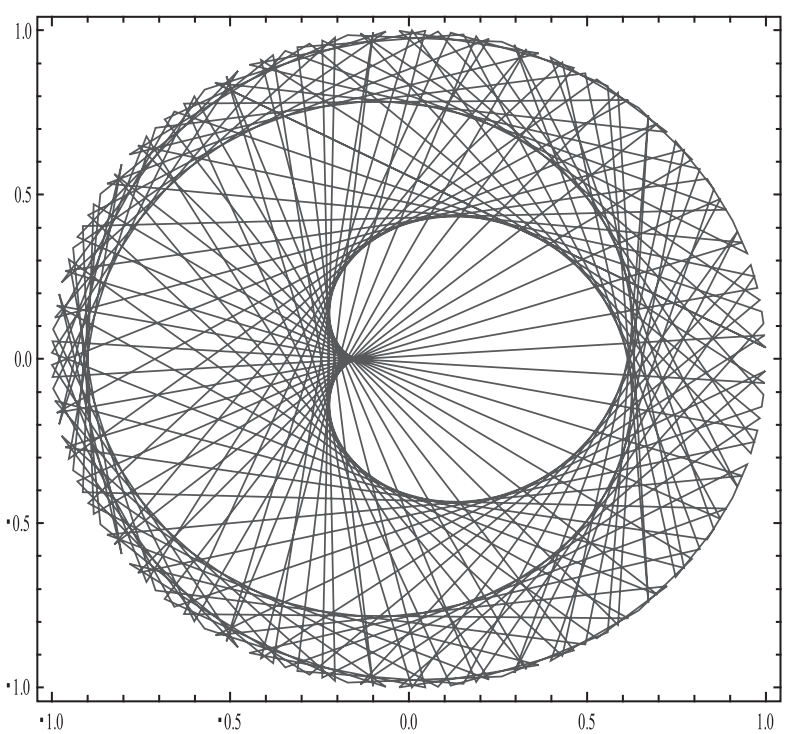

Fig. 7 IQ Orbit of Primitive Root Code $(p=173, q=59)$

る。つまり，カオスを特徴づける原始根qによってパラ メトライズされるのである。ここで，例として， $p=173$ の時を見てみよう

これらのFig. 5から Fig. 7に描く原始根符号の軌道( 卜 ラジェクトリー) は, 原始根 $q$ 倍に位相を拡大する複素平 面上のカオス力学系の周期 $p-1(=172)$ の周期軌道に相 当する周期軌道パターンであり, 通信用のIQ平面上の 符号遷移図とみなすことができる。この原始根符号の軌 道パターンが，回転対称性を持たないことから，直交性 と, カオスの混合性に由来して時間相関が急速に消える という特性を併せ持ち, 信号解析やスペクトル搪散通信 に優れた特性を有することが最近示されている11)。

\section{5. おわりに}

最後に，本解説で紹介した研究成果がレーザーカオス 
の分野へどの様なインパクト, 可能性があるのかを示 す。まず第2章で見た様にレーザーカオス信号は“自然な カオス性を持つ直交基底”の線形和と分解でき, 逆に容 易に基底信号を既知としないブラインド信号分離が可能 であることから，単純なレーザーカオス信号とデータの 和で与えられるカオス通信システムでは，レーザーカオ ス信号とデータの線形和を, 複数ポイントで独立に観測 できる様になったとすると，レーザーの信号源の特徴を 知らなくてもICAにより分離でき，データが抽出できて しまう可能性が示唆される。つまりレーザーカオス信号 に対するICAの分離性能は逆に言えば，単純なレーザー カオス信号とデータの線形和からなるカオス信号が秘話 性を失うことを意味し, ICAによる分離性能を考慮に入 れたセキュリティ評価が必要となる。つまり，秘話性 (情報セキュリティ)と信号分離性能のトレードオフの関 係を示唆する。 また, 広帯域のカオス信号を信号基底と する通信システムを構築するスペクトル分解の基礎理論 が, 第3章で解説した力学系の混合性に由来するルベー グスペクトル解析によって与えられた，更に，第5章の 原始根符号を活用した，カオススペクトル解析により， 実際のシステムによって観測された複雑なレーザー信号 が, 純粋なランダム信号か, 決定論的カオスの性質を持 つカオス性をもつかのカオス性の判定をより明瞭に行う ことができると期待される。周波数スペクトルによる フーリエ解析だけでは，連続スペクトルがただちにカオ ス性を示すものではなく，ランダム信号である可能性を 排除しないが, ここで紹介したカオススペクトル解析に よれば，僅かな“カオススペクトル成分が検出できれば, 混合性を持つカオス性を厳密に検出できる”からであ る。複雑な信号を基底とする新しい通信システムの構築
だけでなく，複雑な信号理解という観点から，今後のカ オスを基底信号として信号を展開するカオス解析の理論 的発展と, 幅広い現象への応用が期待される.

\section{謝 辞}

本研究は, NEDO若手グラントNo. 05A15502a “ICA通 信用チップの研究開発”によりサポートされました。 ここに 謝意を表します。また，末筆ながら，浅学な著者に本論 文執筆の機会を与えていただいた、レーザー学会「レー ザー研究」編集委員長, 編集委員会の皆様に心より御礼 申しあげます。

\section{参考文献}

1) K. Umeno: Phys. Rev. E. 55 (1997) 5280

2) K. Umeno: Nonlinear Analysis 47 (2001) 5753.

3）梅野健：複雑系と通信, 複雑系としての情報システム, （共立出版, 2007）181.

4) K. Umeno: Nonlinear Phenomena in Complex Systems 10 (2007) 170.

5) M. Kuraya, A. Uchida, S. Yoshimori, and K. Umeno: Opt. Express 16 (2008) 725.

6) M. Kuraya, A. Uchida, S. Sano, S. Yoshimori, and K. Umeno: Electron. Lett. 44 (2008) 248.

7) S. Kim and K. Umeno: IEICE Electron. Express 5 (2008) 510

8) K. Umeno: Japanese Patents No. 4276294 (Filed on July 16, 2008, Granted on March 13, 2009, Published on June 10, 2009) and No. 4313434 (Filed on Nov.21, 2008, Granted on May 22, 2009, Published on August 12, 2009), US Patent Application No. 20100232523 (Published on September 16, 2010).

9) J.-F. Cardoso and B. H. Laheld: IEEE Trans. on Signal Processing 44 (1996) 3017.

10) V. I. Arnold and A. Avez: Ergodic Problems of Classical Mechanics. (W. A. Benjamin, New York, 1968).

11）高橋亮, 梅野健：システム/制御/情報 55 (2011) 69. 